\title{
The Influence Of Financial Literacy, Social Environment Factors And Cultural Factors To Consumption Behaviour (Survey on Faculty of Economics Students, Manado State University-Indonesia)
}

\author{
Sjeddie Rianne Watung
}

Faculty of Economics, Universitas Negeri Manado-Indonesia

\begin{abstract}
This research aims at scrutinizing and analyzing how financial literacy, social environmental factors and cultural factors affect consumption behavior of the students of Economics Education Department, Faculty of Economics Universitas Negeri Manado. The research design applies quantitative approach with survey method. The samples consist of 67 students who are chosen as the respondent by using proportionate stratified random sampling. Research instrument is quetionnaire using likert scale as the measurement, and instruments are tested by using validity and reliability tests (SPSS 16 application). Data analysis includes; 1) descriptive analysis, 2) classical assumption test, and 3) multiple linear regression analysis. The results of research are as follows 1). Financial literacy has a significant influence to consumption behaviour of the students, and the magnitude of financial literacy to consumption behaviour of the students is $33.1 \% ; 2$ ). social environmental factors has a significant influence to consumption behaviour of the students, and the magnitude of social environmental factors to consumption behaviour of the students is $34.91 \%$ 3). Social environment factors has a significant influence to consumption behaviour of the students, and the magnitude of social environment factors to consumption behaviour of the students is $32.4 \%$, and 4) Financial literacy, social environmental factors and cultural fctors have a significant influence to consumption behaviour of the students, and the magnitude of social environmental factors to consumption behaviour of the students is $83.5 \%$. It can be concluded that financial literacy, social environmental factors and cultural factors partially and simultaneously affect consumption behaviour of the students of, Faculty of Economics Universitas Negeri Manado.
\end{abstract}

\section{Keywords: Consumption Behavior, Financial Literacty, Social Environment, Cutural Factors}

\section{Introduction}

From the academic aspect, students are registered in an university and meet the requirement to enroll in particular university or college. In the campus environment, students undergo certain learning process based on learning outcome. The success of learning process is measured from students' ability to understand, respond, and implement concepts in their personal and social life. The ability of adapt themselves with the life of campus also proves the success to gain their undergraduate degree.

Students represent the intellectual individuals having mature perspective, attractive and neat look, and polite behaviour. These stereotypes lead students to be attractive (Purnomo, 2011). Social support, popularity, choices for spouses and carrier depend on personal attractiveness (Hurlock, 1980). However, campus environment tends to create an image of individualism and ignorance. Campus environment faces different strategies and techniques from the outside environment. The way how students socialize with other friends is also different depending on the allowance they get from parents. Students from rich family have different life style from those of poor family.

Soegito (1996) in Parma (2007) claims that consumptive behavior of the Indonesian people is more excessive than that of other Southeast countries. The saving rate the Indonesian people is lower compared to other countries such as Malaysia, Phillipine and Singapore. It proves that the Indonesian people prefer to spend money for purchasing unnecessary goods or follow consumerism to sustain their luxurious life style 
and high status. Consumptive behavior is perceived as consumerism because people tend to purchase up-todate products although they do not need them. Unconsciously, consumerism has embedded as culture and turned to be a social disease potential to create the individual and materialistic society. In its worst consequence, consumerism leads to hedonistic society. The symptom is visible since a group of society love buying luxurious products and perceive them as prestige and honor to fulfill their desire.

Financial literacy is a concept which describes someone's capability to apply their knowledge about financial aspect in the effort to acquire their daily needs and rise saving rate. Harun and Isa (2009) found that the majority of university students in Malaysia have low financial literacy, so they do not make right decision related to managing wisely their money for daily life. Orton (2007) emphasizes that financial literacy is inseparable aspect in human life, for it can serve as useful consideration before making a decision. Facts gathered from many countries show that the financial literacy is quite low. Byrne (2007) argues that low financial literacy leads to inaccurate financial management and bias in preparing a prosperous future when someone is no longer productive.

Consumptive behavior is closely related to an individual decision when buying goods or spending incomes. Decision to buy in regard of consumers' behavior concept elaborates that many factors such as belief, attitude, values, and social environment have contributed to this decision. Thus, decision making process in choosing goods and service also depends on external and internal aspects of the customer, one of which is culture. Culture plays a role as the main character of a society which makes certain society peculiar. Some underlying elements in culture are values, language, myth, customs, rites, law and artefacts, or products passed down from generation to generation (Lamb, Hair, and Daniel, 2011).

This becomes recurrent habit although they do not have their own income. Now, there emerges the tendency of ineffective consumption in which university students no longer consider consider their parents' income and follow newest mode and trends. This consumptive behavior is greatly influenced by television advertisement and friends' persuasion. The inclination of having ineffective consumption as explained before is growing although the parents are not able to provide luxurious facilities due to the low economic condition. Some university students keep buying luxurious products although they do not quite need them by using their tuition for the sake of prestige and satisfaction. This condition is common among the students of Economics Education Department, Faculty of Economics Universitas Negeri Manado.

Based on the explanation and some grounded consideration, this research specifically aims at exploring and analyzing the influence of financial literacy, sociocultural factir and culture affect consumption behavior of the students of Economics Education Department, Faculty of Economics Universitas Negeri Manado.

\section{Literature review \\ Financial Literacy}

Some opinions are delivered about financial literacy. Lusardi \& Mitchaell (2007) defines financial literacy as financial knowledge which has a goal to achieve prosperity. Orton (2007) emphasizes that financial literacy is an integral part of one's life because financial literacy is a useful tool for making informed financial decisions. However, from experience in many countries, financial literacy is still relatively low. According to Huston (2010), financial literacy is a part of human capital that can be used in financial activities to increase the expected lifetime benefits of consumption. According to the Financial Services Authority, financial literacy is defined as a series of processes or activities to improve the knowledge, competence, skills of the consumers and the wider community so that they are able to better manage their finances (OJK, 2014). Chen and Volpe (1998) emphasize financial literacy on the ability to understand basic concepts of economics and finance, to how to apply them appropriately. Chen and Volpe (1998) describe financial literacy in several aspects, namely general knowledge, savings, insurance and investments in accordance with the management of personal finances. Kharchenko (2011) states that financial literacy is a necessary numerical skill and an understanding of the basic economic concepts needed to educate in the decision to store and borrow.

There are several key elements of skill and knowledge of financial literacy. Oseifuah (2010) and Wise (2013) mention that those elements include Mathematical knowledge and standardized knowledge such as basic numerals and comprehension skills; Financial understanding of the nature and form of money, how money is used and the consequences of consumption decisions; Financial competencies such as understanding the key features of basic financial services, attitudes in using money and savings, understanding financial records and realizing the importance of reading and maintaining them; awareness of 
the risks associated with financial products, and understanding the relationship between risk and income; and Financial responsibility, namely the ability to make informed decisions about financial issues, knowledge on the rights and responsibilities of consumers, the ability, and the trust to seek help when something goes wrong.

\section{Social environmental factors}

According to Kotler (2010), a person's reference group consists of all groups that have a direct and indirect influence on one's attitudes or behavior. Groups that have a direct influence on a person are called membership groups, and groups which have an indirect influence on a person are called aspirational groups. The family is the most important consumer buying organization in the community, and family members are the most influential primary reference group. In fact, if the buyer no longer interacts deeply with his family, the influence of the family on buyer behavior can remain significant (Kotler, 2010). Someone participates in many groups throughout his life. The person's position in each group can be determined by role and status. Roles include activities expected to be performed by a person. Each role produces status. People choose products that can communicate their roles and status in society. Therefore, marketers should be aware of the potential status symbols of products and brands (Kotler, 2010

\section{Cultural Factors}

Culture is the fundamental factor which determines someone's desires and behaviors. Culture is the most important factor in decision making and purchasing behaviors (Setiadi, 2003), (Lamb, 2001). Culture refers to the habits of a society in response to something that is considered to have values and habits. It can start when they receive information. It depends on their social position in society and their knowledge of what they feel. Culture is a force which regulates human behavior. It consists of a set of behavior patterns that are transmitted and maintained by members of a particular society in various ways (Arnolds \& Thompson, 2005). For example, members in the same culture have common patterns of instruction language and imitation and they share the same value. These values tend to influence consumer behavior and set the selection criteria used by individual consumers (Tahmid Nayeem, 2012). Culture is a group of social values accepted by society as a whole and spread to its members through language and symbols. Each culture consists of smaller sub-cultures that provide more specific identification and socialization to its members. Subcultures include nationality, religion, race and geographical area (Anoraga, 2000). Kotler (2010) says that culture is the most fundamental factor which determines desire and behavior.

According to Baudrillard (Featherstone, 2008), Culture, in relation to consumption, is a systematic action to manipulate signs. Objects must contain or even become signs to be objects of consumption. Baudrillard explains that the society of consumption has unconsciously made consumption a center of life activity with a strong desire for having a product indicated by the excessive desire for shopping. In society the consumption, perception of goods have transformed from the needs having exchange rate and usage value into a symbol of image or prestige. The meaning of consumption shifts from meeting the needs of changing into fulfilling desires. Consumer culture is a new culture in consumption parameters that highlights the underpinning of a shift in consumption. Consumption of goods that have decades of image value has become a phenomenon. Baudrillard in Featherstone (2008) explains that consumer culture is a postmodern culture, a culture of superficiality within which culture values in transvaluation (evaluated by new principles) and art has surpassed reality.

\section{Consumption behavior}

Samuelson \& Nordhaus (1996) define consumption is the act of spending money to purchase goods and acquire services in order to gain satisfaction and to fulfill needs. Consumption has broader definition, that is, the end product or service needed to satisfy human needs. End product or service refer to goods and service which are readily consumed. These products consist of products which can be consumed only once or twice (Nopirin, 1993).

To acquire products and service needed, an individual or society have to spend money they gain from their income (both permanent or temporary incomes). Dusenberry in Reksoprayitno (2000) explains that consumption rate in a society is determined by the income level. The decrease of income will not decrease the spending for their consumption. They tend to decrease saving rate to maintain consumption level. The increasing income will speed up their consumption rate although it is not too significant. Further, saving will 
increase. It happens continuously no matter how much the salary is. In short, the consumption rate depends on income.

Marcuse in Storey (2006) develops several arguments about consumption by showing that consumerism leads to fake needs serving as social contro (for example, people recognize themselves in their commodity; they find solace in cars, hi-fi equipment, luxurious houses, beauty products and so forth). This mechanism binds an individual within the community, and new end products become social control. Based on the theory of consumption behavior, utility and satisfaction are important to explain the concept of modern economy. Both terms are closely related to function and satisfaction which someone gains from consuming those products (Sukirno, 2006).

The changes of consumption value into more consumptive behavior is the irrational decision due to the disappointment and differences during decision making process. Consumption behavior is one of inseparable behaviors from human life. Wahyuningtyas (Enrico, dkk, 2014) argues that consumptive behavior trespasses nation boundaries in which Indonesia also gets the impact. The facts show that most Indonesians to have consumptive behavior, love new products, and spend most of their income to buy up to date products (Pratama, 2013). Consumptive behavior occurs due to several factors.. Sumartono (2002) explains that consumptive behavior found among university students results from internal factor indicated from motivation, self pride, observation, learning process, personality and self concept. This behavior also emerges from external factors such as culture, social class, social groups, reference, and family.

In the concept of customer behavior, Kotler and Armstrong (2007) disclose that customer behavior is greatly affected by cultural, social, personal and psychological characteristics. Mangkunegara (2008) defines customer behavior as a series of actions which individuals, groups, and organization undertake during the decision making process to acquire, use goods and service economically. This can be influenced by the environment. Customer behavior includes decision which someone takes to compete and decide how to get and use products and services.

\section{Research Method}

This research design uses quantitative approach with survey method, which aims to find out how much financial literacy, social environmental factors, and cultural factors affect the consumption behavior of economics education students at Faculty of Economics, Universitas Negeri Manado. The population is all active students majoring in Economics education department with a concentration of students in accounting education enrolled in academic year 2016/2017. They are 140 students (4 classes) studying in even semester. The total sample is 67 students who serve as respondents through proportionate stratified random sampling.

The research variables include financial literacy $\left(\mathrm{X}_{1}\right)$ as the independent variable. Financial literacy is defined as knowledge and understanding of financial concepts in an effort to achieve prosperity. Indicators of financial literacy are: general knowledge of finance, savings, insurance and investment; Social environmental factors $\left(\mathrm{X}_{2}\right)$ are defined as individual places (students) interact that provide value. Indicator: social class, reference group, and family; and Cultural Factors $\left(\mathrm{X}_{3}\right)$ are defined as the habits of a society in response to something that is considered to have values and habits which can start from receiving information. It can seen also from their social position in society and their knowledge of what they feel. Indicator: values, habits, and beliefs. The dependent variable (Y) is the consumption behavior. Consumption behavior is a tendency to consume goods or services in excess or no limit and more concerned with the desire factor than the needs. Indicators: fulfillment of needs according to intensity, application of economic principles in consumption, consumption motives, priority scale in consumption, and selective in consumption.

The research instrument is questionnaires, with a list of closed questions and statements. The questionnaire used in this study was adopted from previous studies, but has been modified in accordance with the conditions undertaken in this study. Validity test is performed by comparing correlation index of product moment pearson with 5\% significance level with critical value. The result is considered valid if significant value of $\mathrm{t}(\mathrm{sig} \mathrm{t}$ ) from Pearson correlation result is less than 0.05 (Sugiyono, 2013). Test reliability is conducted by using alpha cronbach. The result is reliable if the value of $r_{11} \geq 0.6$ and if the value of $r_{11} \leq 0.6$, the result is not reliable (Sugiyono, 2013).Data analysis techniques include (SPSS 16 program application): 1) Descriptive analysis includes: mean and standard deviation; 2) Classic assumption test, including: Normality test, linearity test, multicolinearity test, heterodasticity test, and autocorrelation 
test; and 3) Multiple linear regression analysis, including: Regression equation model, Hypothesis test (partial test with $\mathrm{t}$ test and simultaneous test with $\mathrm{F}$ test), and Coefficient of determination.

\section{Result and Discusion}

Result

All item shows the validity test of 34 items is $r_{\text {count }}>r_{\text {table }}$ (sig $t<0.05$ ). It means that all items fulfill the valid requirement and the variable reliability test $\mathrm{X}_{1}, \mathrm{X}_{2}, \mathrm{X}_{3}$ dan $\mathrm{Y}$ have $\mathrm{C} \alpha$ value $\geq 0.6$, it means that the value is reliable. The Kolmogrov- Smirnov test result uses the value convention: If sig value is $>0.05$, so the data is distributed normally, and if the sig value is $<0,05$, so the data is not distributed normally. With that condition, the test result in table 4 shows that test distribution is normal. Thereby, for Normal P-P plot result. The normality assumption is intended for regression model residual is normally distributed.

The linearity test uses the Compare Means test from SPSS version of 16 for windows. Based on the analysis that has been done, it is revealed that: 1) Financial literation with student behavior consumption gets anova score table $F=272.058$, with $p=0.000 \quad(p<0.05)$, which means that both variables have linier relation; 2) The social environment factor with student consumption behavior gets the anova score table for $\mathrm{F}=190.255$, with $\mathrm{p}=0,000(\mathrm{p}<0,05)$, which means that both variables have linier relation; and 3$)$ The cultural factor with student consumption behavior gets the anova score table: $F=110.541$, with $p=0.000$ $(\mathrm{p}<0.05)$, which means that both variables have linier relation. So, it can be concluded that those three independent variables seperatedly choose the linier relation. The multicolliniearity test (output SPSS 16) is in Collinearity statistic. As the criteria for the multicollinearity does not occur, the VIF value $<10$. Based on the result, it shows that the VIF value for financial literacy variable, the social environment factor, and cultural factor is $<10$, so it can be concluded that there is not multicolliniearity occurence in these three dependent variables.The autocorrelation test can be seen in summary model of Durbin-Watson. The result of Durbin Wason is for 2.421, so it means that the value is between both du value (1.731) and 4du value (2.481). Based on the result that is obtained, it can be concluded that in this regression model, the autocorrelation does not occur.In Residual Column, it can be seen that the correlation coefficient is low or the significant value (Sig. (2-tailed)) of each independent variable is above $5 \%$, it means that the independent variables do not have relation with the residual. Thus, it can be concluded that there is not heteroscedasticity in this linier regression model. The analysis of multiple regression can be seen on table 1. Table 1. Coefficients ${ }^{\mathrm{a}}$

\begin{tabular}{|c|c|c|c|c|c|c|}
\hline \multirow{2}{*}{\multicolumn{2}{|c|}{ Model }} & \multicolumn{2}{|c|}{$\begin{array}{c}\text { Unstandardized } \\
\text { Coefficients }\end{array}$} & \multirow{2}{*}{$\begin{array}{c}\text { Standardi } \\
\text { zed } \\
\text { Coefficien } \\
\text { ts } \\
\text { Beta }\end{array}$} & \multirow[t]{2}{*}{$t$} & \multirow[t]{2}{*}{ Sig. } \\
\hline & & $B$ & $\begin{array}{c}\text { Std. } \\
\text { Error }\end{array}$ & & & \\
\hline \multirow[t]{4}{*}{1} & (Constant) & -6.709 & 2.650 & & -2.531 & .014 \\
\hline & Financial Literacy & .378 & .129 & .331 & 2.942 & .005 \\
\hline & $\begin{array}{l}\text { Social } \\
\text { Environment } \\
\text { Factor }\end{array}$ & .863 & .252 & .349 & 3.427 & .001 \\
\hline & Cultural Factor & .544 & .123 & .324 & 4.428 & .000 \\
\hline
\end{tabular}

From the above table, the regression equation is: $\mathrm{Y}=-6.709+0.378 \mathrm{X}_{1}+0.863 \mathrm{X}_{2}+0.544 \mathrm{X}_{3}+\mathrm{e}$ That multiple linier regression equation shows the independent variables (financial literacy, social environment factor, cultural factor) that are analyzed gives positive influence toward the dependent variable (student consumption behavior).

The equation regression model can be explained as followed: 1) The constant value is for 6,709 so it means if the financial literacy, social environment factor, and cultural factor are considered constantly or there are not any changes, the student consumption behavior is for $-6.709 ; 2)$ The financial literacy $\left(\mathrm{X}_{1}\right)$ has regression coefficient for 0.378 , it means that every rise of financial literacy for one unit will improve the student behavior for 0.378 with assumption that other variables are constant. The positive sign shows the 
same direction relation between financial literacy and student consumption behavior; 3) The social environmental factors $\left(\mathrm{X}_{2}\right)$ has regression coefficient for 0.863 , it means that every rise of social environmental factors variable for one unit will improve the student behavior for 0.863 with assumption that other variables are constant. The positive sign shows the same direction relation between social environment factor and student consumption behavior; and 4) The cultural factors $\left(\mathrm{X}_{3}\right)$ has regression coefficient for 0.544 , it means that every rise of culture factor variable for one unit will improve the student behavior for 0.544 with assumption that other variables constant. The positive sign shows the same direction relation between cultural factor and student consumption behavior.

\section{Partial T test. The Stipulation}

$\mathrm{H} 0$ : $\mathrm{b} 1, \mathrm{~b} 2, \mathrm{~b} 3=0$, it means that the variant of independent variable can explain the dependent variable and there is influence between those two variables that are tested.

$\mathrm{Ha}: \mathrm{b} 1, \mathrm{~b} 2, \mathrm{~b} 3 \neq 0$, it means that the variant of independent variable can not explain the dependent variable and there is not any influence between those two variables that are tested.

Test is done through the $t$ test by comparing the $t_{\text {count }}$ with $t_{\text {table }}$ at $\alpha 0.05$. If the calculation result shows: 1). $t_{\text {count }} \geq t_{t a b l e}$, so Ho is refused and Ha is accepted, it means that the independent variable variation can explain the dependent variable and there is influence between those two variables that are tested. 2) $t_{\text {count }}<$ $t_{\text {table, }}$ so Ho is accepted and Ha is refused, it means that the independent variable variation can not explain the dependent variable and there is not influence between those two variables that are tested.

Based on table 8, the partial test (t test) can be explained as followed: 1). The result of the calculation is $t_{\text {count }}$ for $2.942>t_{\text {table }}$ is for 1.980, so Ho is refused and H1 is accepted, this means there is influence between financial literacy and student consumption behavior. The magnitude of financial literacy that influences the student consumption behavior is for 0.331 or $33.1 \%$ (Standardized Coefficients) in significant level of 0.05 $<0.05$, thus it can be stated significant; 2). The calculatiom result is $t_{\text {count }}$ for $3.427>t_{\text {table }}$ is for 1.980 , so Ho is refused and H1 is accepted, this means there is influence between social environment factor and student consumption behavior. The magnitude of social environment factor that influences the student consumption behavior is for 0.349 or $34.9 \%$ (Standardized Coefficients) in significant level of $0.001<0.05$, thus it can be stated significant; 3 ). The calculatiom result is $t_{\text {count }}$ for $4.428>t_{\text {table }}$ is for 1.980 , so Ho is refused and $\mathrm{H} 1$ is accepted, this means there is influence between cultural factor and student consumption behavior. The magnitude of cultural factor that influences the student consumption behavior is for 0.324 or $32.4 \%$ (Standardized Coefficients) in significant level of $0.000<0.05$, thus it can be stated significant;

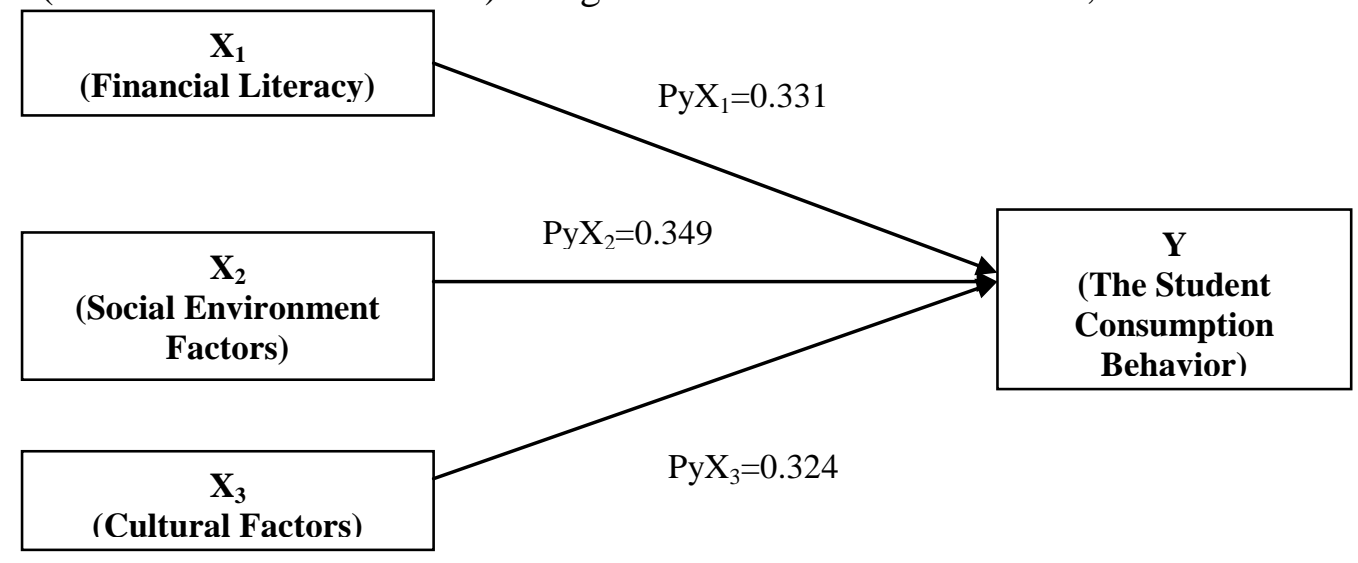

Figure 1. Model of Empirical Research

\section{The Stipulant F Test:}

From the result shows that: The $F_{\text {count }}$ value $(112.000)>F_{\text {table }}(2.44)$ and the Sig research value $\left(0.000^{\mathrm{a}}\right)<$ the significant level value (0.05). This means the alternative $(\mathrm{Ha} / \mathrm{H} 1)$ is accepted and null hypothesis is refused., so it can be concluded that the regression model that is estimated is proper, with statement that financial literacy, social environmental factors, and cultural factor simultaneously influence the student consumption behavior significantly at Economics Education of Economics Faculty State University of Manado.

The determination coefficient in this research aims to explain the influence of independent variables (social environmental factors, and cultural factor) toward the dependent variable (the student consumption 
behavior). In order to know the contibution magnitude simulataneously, it is based on the Adjusted R Square value at summary model table below:

the Adjusted R Square value is 0.835 . This shows the proportion of financial literacy variable influence financial literacy, social environmental factors, and cultural factors toward the student consumption behavior is for $83.5 \%$. This means, the financial literacy, social environment factor, and cultural factor simultaneously influence the student consumption behavior significantly at Economics Education of Economics Faculty State University of Manado for $83.5 \%$ while the $16.5 \%(100 \%-83.5 \%)$ are influenced by other variables that are not in this multiple linier regression model.

\section{Discussion}

The influence of financial literacy, social factor and culture on consumption behaviour :

The findings of the study prove that financial literacy, social environmental factors, cultural factors simultaneously have a significant and positive effect on consumption behavior of students of Economics Education Faculty of Economics, Universitas Negeri Manado. This is indicated by the $F_{\text {hitung }}$ value $(112,000)>F_{\text {tabel }}(2.44)$ and the Sig value of the research $(0.000 a)$ <ignificant level value (0.05). This means that the estimated regression model is feasible, with a simultaneous contribution of $83.5 \%$. This finding supports Lusardi \& Mitchell (2010), Chen and Volpe (2002), Lutfi \& Iramani (2008), Setiadi, (2013), Lamb (2001), Kotler and Keller (2006), Inderjeet Sethi and AS Chawla (2014), Nayeem, Tahmid (2012) who revealed that consumption behavior is generally influenced by factors explained in this research. Empirical results describe that financial literacy, social and cultural factors give a real contribution to consumer consumption behavior. This means that with consideration of opinion empirically proves that the higher value obtained by the three independent variables increases the value of consumption behavior of students in Economics Education, Faculty of Economics, Universitas Negeri Manado.

The influence of financial literacy on consumption behaviour :

The findings of the study prove that the financial literacy has a significant and positive effect on consumption behavior of the students in Economics Education, Faculty of Economics, Universitas Negeri Manado. This is shown by $t_{\text {hitung }}$ of 2,942> $t_{\text {tabel }}$ of 1980, with the influence of financial literacy on student consumption behavior of 0331 or $33.1 \%$ at a significant level of $0.01<0.05$, so it can be stated significant. The results support the opinion of Lusardi \& Mitchell (2010), Chen and Volpe (2002), Lutfi \& Iramani (2008), who explain that the economic and financial concepts of knowledge give positive value to consumer behavior in shopping and purchasing. This means that higher value of financial literacy will also increase the consumption behavior of students in Economics Education, Faculty of Economics, Universitas Negeri Manado.

The influence of social environmental factors on consumption behavior:

The findings of the study prove that the social environmental factors has a significant and positive effect on consumption behavior of the students in Economics Education, Faculty of Economics, Universitas Negeri Manado. This is shown by $t_{\text {hitung }}$ of $3.427>t_{\text {tabel }}$ of 1.980 , with the influence of financial literacy on student consumption behavior of 0349 or $34,9 \%$ at a significant level of $0.01<0.05$, so it can be stated significant. The results support the opinion of Lamb (2001), Kotler dan Keller (2006), who explain that the social factor gives positive value to consumer behavior in spending their income. This means that higher value of social environmental will increase the consumption behavior of students in Economics Education, Faculty of Economics, Universitas Negeri Manado.

The influence of cultural factors on consumption behavior:

The findings of the study prove that cultural factors has a significant and positive effect on consumption behavior of the students in Economics Education, Faculty of Economics, Universitas Negeri Manado. This is shown by $\mathrm{t}_{\text {hitung }}$ of $34.428>\mathrm{t}_{\text {tabel }}$ of 1.980 , with the influence of cultural factors on student consumption behavior of 0324 or $32,4 \%$ at a significant level of $0.01<0.05$, so it can be stated significant. The results support the opinion of Setiadi, (2003), Lamb (2001), Kotler and Keller (2006), Inderjeet Sethi dan AS Chawla (2014), Nayeem, Tahmid (2012), Anoraga (2000), who explain that cultural factors gives positive value to consumer behavior in spending their income. This means that higher value of culture will increase the consumption behavior of students in Economics Education, Faculty of Economics, Universitas Negeri Manado. 


\section{Conclusion}

Based on the analysis result and discussion, the conclusions of this research are:

- Financial literacy, social environment factor, and cultural factor relate, influence, and contribute positively toward the student consumption behavior at Economics Education of Economics Faculty Universitas Negeri Manado.

- Financial Literacy relate, influence, and contribute positively toward the student consumption behavior at Economics Education of Economics Faculty Universitas Negeri Manado.

- Social environment factor relate, influence, and contribute positively toward the student consumption behavior at Economics Education of Economics Faculty Universitas Negeri Manado.

- Cultural factor relate, influence, and contribute positively toward the student consumption behavior at Economics Education of Economics Faculty Universitas Negeri Manado.

The limitation of this research is that respondents only students from one faculty. If further research is to be conducted, it is hoped that the respondents can be taken with a larger number by involving students from all faculties.

\section{Implication and Recomendation}

Based on the finding, the research has implications as followed:

1) The three exogen variables have capability in explaining the student consumption behavior. This shows that financial literacy, social environment factor, cultural factor, can give value toward student and costumer generally in consumption behavior.

2) The consumption behavior is the series of activities of action and decission taking process for consumption activity.

3) Those three variables explain that the consumption behavior have given changes for students in behaving. So the understanding of knowledge in managing money, social life, and cultural influence, can be regarded in costumer behavior concept.

\section{Recomendation:}

1) This research focuses on heterogen students in social, culture and also knowledge. Thus, to generalize in certain social and culture is too early.

2) There are some numbers of variables that have not been included especially, psychology and physiology variables that are believed in giving strong influence toward the students.

3) In analyzing data accumulation process through questionnaire and quantitative approach is beieved that it has not been capable in answering the research problems. So, it is needed to do the research with qualitative approach.

\section{References}

[1] Anoraga, Panji. 2000. Manajemen Bisnis. Jakarta: PT. Rineka Cipta

[2] Byrne, A. 2007. Employee saving and investment decisions in defined contribution pension plans: survey evidence from the U.K. Financial Services Review 16 (2007) 19-40

[3] Chen, Haiyang and Volpe, Ronald P. 2002. Gender Diffrences in Personal Financial Literacy Among College Students. Financial Services Review. Vol 11. Pp 289-307.

[4] Enrico, A., Aron, R., \& Oktavia, W. (2014). The factors that influenced consumptive behavior: A survey of university students in Jakarta. International Journal of Scientific and Research Publications, 4(1), 1-5

[5] Hartaji, D. A, 2012. Motivasi Berprestasi pada Mahasiswa yang Berkuliah dengan Jurusan Pilihan Orang Tua. Fakultas Psikologi Universitas Gunadarma.

[6] Hurlock, E. B. (2004). Psikologi perkembangan suatu pendekatan sepanjang rentang kehidupan. Jakarta: Erlangga

[7] Huston, S. J. 2010. Measuring Financial Literacy. The Journal of Consumer Affairs, Vol. 44 No. 2. Hal. 296-315

[8] Inderjeet Sethi dan AS Chawla. 2014. Journal of Marketing Management. American research Institute for Policy Department, USA. March 2014. Vol. 2. No 1. Pp. 97-110.

[9] Kharchenko, Olga. 2011. Financial Literacy in Ukraine: Determinants and Implication for Saving Behaviour. Ukraine: Kyiv School of Economic. 
[10] Kotler, P and Keller, K.L, 2006. Marketing Management. Edisi 12. Pearson Education: New Jersey.

[11] Kotler, P. 2010. Manajemen Pemasaran. Edisi Melenium. PT. Prenhalindo. Jakarta.

[12] Kotler, P. dan Armstrong, G. 2007. Dasar-dasar Pemasaran. Jilid 1. Edisi Tujuh. Penerbit Prentice Hall-Inc. Jakarta

[13] Lamb, H. 2001. Pemasaran. Edisi Pertama. Salemba Empat. Jakarta

[14] Lamb, H dan McDaniel. 2001. Pemasaran Buku1 edisi pertama. Jakarta: Salemba Empat.

[15] Lusardi, A \& Mitchell, O. S. 2010. Financial Literacy Among The Young. The Journal of Consumer Affairs. Vol 44 No. 2. Pp. 358-380.

[16] Lutfi \& Iramani. 2008. Financial Literacy Among University Student and Its Implications to The Teaching Method. Jurnal Ekonomi Bisnis dan Akuntansi Ventura. Vol. 11 Pp 2.

[17] Mangkunegara P. A., 2008. Manajemen Sumber Daya Manusia. Cetakan ke-3. Bandung: PT.

[18] Mankiw, N. Gregory. 2000. Teori Makroekonomi. Edisi Keempat. Terjemahan: Imam Nurmawan. Jakarta: Erlangga

[19] Nayeem, Tahmid. 2012. Cultural Influences on Consumer Behaviour. International Journal of Business and Management. Canada: Canadian Center of Science and Education. Vol.7, No. 21;2012.

[20] Nopirin, 1993. Ekonomi Moneter. Edisi 4. Cetakan Kedua, Penerbit BPFE, Yogyakarta

[21] Orton, L. 2007. Financial Literacy: Lessons from International Experience. CPRN Research Report September 2007

[22] Oseifuah, Emmanuel Kojo. 2010. Financial Literacy and Youth Entrepreneurship in South Africa. Thohoyandou: Department of Accounting and Auditing University of Venda

[23] Otoritas Jasa Keuangan. 2014. Strategi Nasional Literasi Keuangan Indonesia. Jakarta.

[24] Pratama, A. F. 5 Desember 2013. Ekonomi Indonesia ditopang pola konsumtif masyarakat. Tribun News. Diakses dari http://www.tribunnews.com/ bisnis/2013/12/05/ekonomi-indonesia-ditopangpola-konsumtif-masyarakat

[25] Reksoprayitno, Soediyono, 2000. Ekonomi Makro, Yogyakarta: Penerbit BPFE

[26] Samuelson, P. A. Dan Nordhaus W.D. 1996. Makro Ekonomi. Edisi ke-17. Cetakan ketiga. Jakarta: Erlangga

[27] Setiadi, N. 2013. Perilaku Konsumen: Konsep dan Implikasi Untuk Strategi dan Penelitian Bisnis Pemasaran. Prenada Media. Jakarta.

[28] Sopian 2017. Ini Kata Presiden Jokowi Soal Generasi Y., Majalah Kartini |04/08/2017 - 17:01

[29] Storey, John. 2006. Cultural Studies dan Kajian Budaya Pop. Yogyakarta: Jalasutra

[30] Sugiyono, 2013. Metode Penelitian Pendidikan: Pendekatan Kuantitatif, Kualitatif, dan R\&D. Bandung: Alfabeta.

[31] Sukirno, Sadono. 2006. Mikro Ekonomi Teori Pengantar. Jakarta: Rajagrafindo Persada

[32] Sumartono. 2002. Terperangkap dalam Iklan: Meneropong Imbas Pesan Iklan Televisi. Bandung: Alfabeta.

[33] Sumarwan.1993. Keluarga Masa Depan dan Perubahan Pola Konsumsi. Warta Demografi. Jakarta: LD.FEUI

[34] Tempo.com 22/07/2017 Pesan Presiden Jokowi kepada Generasi Y: Saya Pancasila; https://www.msn.com/id-id/berita/nasional/pesan-presiden-jokowi-kepada-generasi-y-sayapancasila/ar-AAoAcRW.

[35] Wise, Sean. 2013. The Impact of Financial Literacy on New Venture Survival. International Journal of Business and Management, Volume 8, No. 23 